\title{
Phosphogypsum and Black Steel Slag as Additives for Ecological Bentonite-Based Materials: Microstructure and Characterization
}

\author{
Achraf Harrou ${ }^{1}$, El Khadir Gharibi ${ }^{1, *} \mathbb{B}$, Yassine Taha ${ }^{2}{ }^{1}$, Nathalie Fagel $^{3}$ and \\ Meriam El Ouahabi ${ }^{3}$ (D) \\ 1 Laboratory of Applied Chemistry and Environment Team of Mineral Solid Chemistry, Faculty of Sciences, \\ Mohammed First University, Oujda 60000, Morocco; A.harrou@ump.ac.ma \\ 2 Mining Environment and Circular Economy Program (EMEC), Mohammed VI Polytechnic \\ University (UM6P), Lot 660.Hay Moulay Rachid, Ben Guerir 43150, Morocco; yassine.taha@um6p.ma \\ 3 UR Argile, Geochemistry and Sedimentary Environment (AGEs), Department of Geology, Quartier Agora, \\ University of Liege, Bâtiment, B18, Allée du six Aout, 14, Sart-Tilman, B-4000 Liege, Belgium; \\ nathalie.fagel@uliege.be (N.F.); meriam.elouahabi@uliege.be (M.E.O.) \\ * Correspondence: e.gharibi@ump.ac.ma or gharibi_elkhadir@yahoo.fr
}

Received: 29 September 2020; Accepted: 24 November 2020; Published: 28 November 2020

\begin{abstract}
The Black Steel slag (Ss) and phosphogypsum (PG) are industrial wastes produced in Morocco. In order to reduce these two wastes and to evaluate their pozzolanic reactivity in the presence of water, they were incorporated into bentonite (B) mixed with lime (L). The studied mixtures (BLW, BL-PG-W and BL-PG-Ss-W) were analyzed by X-ray diffraction, Infrared spectroscopy, Raman spectroscopy and SEM/EDX analysis. Compressive strength tests were performed on hardened specimens. The results obtained show that the hydration kinetics of the B-L-W and B-L-PG-W mixtures are slow. The addition of PG to a bentonite-lime mixture induces the formation of new microstructures such as hydrated calcium silicate (C-S-H) and ettringite, which increases the compressive strength of the cementitious specimens. The addition of the $\mathrm{Ss}$ to a mixture composed of $8 \% \mathrm{PG}$ and $8 \% \mathrm{~L}-\mathrm{B}$ accelerates the kinetics of hydration and activates the pozzolanic reaction. The presence of $\mathrm{C}_{2} \mathrm{~S}$ in the slag helps to increase the mechanical strength of the mixture B-L-PG-Ss. The compressive strength of the mixtures BL-W, BL-PG-W and BL-PG-Ss-W increases from 15 to 28 days of setting. After 28 days of setting, $8 \%$ of Sc added to the mixture $8 \%$ PG- $8 \% \mathrm{~L}-\mathrm{B}$ is responsible for an increase of the compressive strength to $0.6 \mathrm{MPa}$.
\end{abstract}

Keywords: bentonite; phosphogypsum; slag; lime; hydration; kinetics; Pozzolanic reactions

\section{Introduction}

Recycling industrial waste as an alternative to reduce natural resource consumption is a recently-developed solution to some environmental and economic problems. China, Europe, Japan and the United States are the worldwide leaders of steel industry production according to the statistics reported by the World Steel Association [1].

In Morocco, the steel industry in the Jorf Lasfar (El Jadida, NE Morocco), represented by the SONASID Company (El Jadida, NE Morocco), i.e., a subsidiary of ArcelorMittal, produces more than 150,000 tons of black steel slag (Ss) per year and recovers $90 \%$ of the slag produced [2]. Black steel slag presents major environmental risks [3]. It contains heavy metals like As and $\mathrm{Cr}$ that can be released into water sources [4]. In particular, arsenic, in small concentrations, is toxic and highly mobile in various $\mathrm{pH}$ conditions, which may leach out into the environment [5-7]. Its chemical composition consists mainly of $\mathrm{CaO}, \mathrm{MgO}, \mathrm{SiO}_{2}, \mathrm{MnO}$ and $\mathrm{FeO}[8,9]$. The slag has a porous morphology and alkaline 
properties. Therefore, it is largely used for the retention of phosphate ions from waste-contaminated water [10-12]. The presence of calcium silicate $\left(\mathrm{Ca}_{2} \mathrm{SiO}_{4}\right)$, Tricalcium silicate $\left(\mathrm{Ca}_{3} \mathrm{SiO}_{5}\right)$, tetracalcium aluminoferrite $\left(\mathrm{Ca}_{4} \mathrm{Al}_{2} \mathrm{Fe}_{2} \mathrm{O}_{10}\right)$ and other mineral components provide to the steel slag hydraulic setting properties [13,14], allowing an increase of compressive strength of dredged marine clays [15]. Steel slag is also successful used as an aggregate in the cement industry [16]. It helps to delay the hydration mechanism of concrete and reduces its mechanical strength [17]. Likely slag activates the hydration of $\mathrm{C}_{2} \mathrm{~S}$ and $\mathrm{C}_{3} \mathrm{~S}$ [18]. In addition, the occurrence of $\mathrm{Fe}_{2} \mathrm{O}_{3}$ in the steel slag decreases the expansion of clay-based material and increases its mechanical strength [19]. In particular, the use of steel slag as aggregate for metakaolinitic-cement enhances its mechanical properties [20]. In addition, steel slag is used in other fields such as civil engineering, mainly to stabilize the swelling behavior of clays in road infrastructure [21].

Phosphogypsum (PG) essentially consists of calcium sulfate dihydrate $\left(\mathrm{CaSO}_{4} \cdot 2 \mathrm{H}_{2} \mathrm{O}\right)$. It is a by-product resulting from the attack of sulfuric acid on phosphate rock to produce phosphoric acid, mainly used in the fertilizer industry. The process of PG production is described by the following reaction [22]:

$$
\mathrm{Ca}_{5} \mathrm{~F}\left(\mathrm{PO}_{4}\right)_{3}+5 \mathrm{H}_{2} \mathrm{SO}_{4}+10 \mathrm{H}_{2} \mathrm{O} \rightarrow 3 \mathrm{H}_{3} \mathrm{PO}_{4}+5 \mathrm{CaSO}_{4} \cdot 2 \mathrm{H}_{2} \mathrm{O}+\mathrm{HF}
$$

The world phosphate industry produces about $250 \mathrm{Mt} / \mathrm{yr}$ of PG [22]. In Morocco, it exceeds $25 \mathrm{Mt}$ /year. PG is produced in large quantities, five tons of $\mathrm{PG}$ for one ton of phosphoric acid [23,24]. PG also contains phosphates under the form of $\mathrm{H}_{3} \mathrm{PO}_{4}, \mathrm{Ca}\left(\mathrm{H}_{2} \mathrm{PO}_{4}\right)_{2} \cdot \mathrm{H}_{2} \mathrm{O}$ and $\mathrm{CaHPO}_{4} \cdot 2 \mathrm{H}_{2} \mathrm{O}, \mathrm{Ca}_{3}\left(\mathrm{PO}_{4}\right)_{2}$, residual acids, fluorids $\left(\mathrm{NaF}, \mathrm{CaF}_{2}, \mathrm{Na}_{3} \mathrm{AlF}_{6}, \mathrm{Na}_{3} \mathrm{FeF}_{6}\right.$ and $\left.\mathrm{Na}_{2} \mathrm{SiF}_{6}\right)$, trace metals $(\mathrm{Cd}, \mathrm{Zn}, \mathrm{Cu}, \mathrm{Cr})$ and organic matter [25]. It can also contain nuclides such as Ra, $\mathrm{U}$ and $\mathrm{Th}$, but do not pose any major leaching environmental risk, except for $\mathrm{Cd}[22,26]$.

Recently, several studies aimed at valorizing PG to improve road pavements and stabilize the swelling behavior of soils have been realized [27-32]. PG was also used as aggregates for bricks masonry materials $[33,34]$ and for the production of cement $[35,36]$. Romero-Hermida et al., [37] studied rheological characteristics of a lime putty obtained as a by-product from the treatment of phosphogypsum waste with a solution of $\mathrm{Na}(\mathrm{OH})$. The putties studied present a similar rheological response as a commercial one. Gu and Chen [38] attested that the addition of PG and fly ash increased the compressive strength of the loess-PG-fly ash mixture due to the formation of nanosilicates gel (C-S-H) gel and ettringite (AF-t). Furthermore, PG promotes the carbonization rate of steel slag [39].

Bentonite, mainly composed of calcium and sodium montmorillonite, is among the most used clays in civil engineering due to its high adsorption capacity [40]. At room temperature, at high $\mathrm{pH}$, and in the presence of water and lime $(\mathrm{CaO})$, bentonite undergoes geoplymerization like a Portland cement through complex pozzolanic reactions.

Our study aims to determine the influence of the addition of black steel slag and phosphogypsum on the mechanical performance of bentonite-based mortar with the presence of lime. This study will also strive to understand the different reaction mechanisms and to identify the hydrated microstructures after the hardness process using several analytical complementary techniques (XRD, IR, RAMAN and SEM/EDX).

\section{Material and Methods}

\subsection{Raw Materials}

The raw bentonite was sampled from the Trebia deposit in the Nador area (North-East Morocco). The traditional lime marketed in Oujda (eastern Morocco) is used to stabilize the swelling behavior of bentonite. The black Ss produced by the ArcelorMittal SONASID company in the Jorf Lasfar (Eljadida, Morocco), is obtained after melting iron scrap in an electric arc furnace. Phosphogypsum (PG), produced by OCP at Jorf Lasfar (El jadida, Morocco). 


\subsection{Experimental Procedure}

The collected samples were ground and sieved to a diameter of less than $250 \mu \mathrm{m}$. Three mortar specimens were prepared with Ss, PG, L and B according to the proportions reported in Table 1. The prepared specimens are cylindrical with $3.4 \mathrm{~cm}$ in diameter and $6.8 \mathrm{~cm}$ in height according to ASTM Standard D1621. The test tubes contain $80 \mathrm{~g}$ of the solid mixed with $38.4 \mathrm{~mL}$ of the distilled water having a W/S ratio of $46 \%$ [31]. The plasticity index and Particle-Size Distribution analysis are determined according to the ASTM D4318 and ASTM D6913, accordingly [41].

The mechanical resistance of the specimens was monitored after 15 and 28 days of setting. For the ES3, EP3 and EL3 test pieces, the mineralogical composition was determined by XRD after 3, 7, 15 and 28 days of setting. All test tubes were immersed in distilled water for $4 \mathrm{~h}$ and the $\mathrm{pH}$ of the solution was measured.

Table 1. Formulations based on the different proportions of raw materials studied.

\begin{tabular}{ccccc}
\hline Mixtures & Ss (wt. $\%)$ & PG (wt. $\%)$ & L (wt. $\%)$ & B (wt. $\%)$ \\
\hline EL1 & 0 & 0 & 2 & 98 \\
EL2 & 0 & 0 & 5 & 95 \\
EL3 & 0 & 0 & 8 & 92 \\
EL4 & 0 & 0 & 11 & 89 \\
EL5 & 0 & 0 & 14 & 86 \\
EL6 & 0 & 0 & 20 & 80 \\
EP1 & 0 & 2 & 8 & 90 \\
EP2 & 0 & 5 & 8 & 87 \\
EP3 & 0 & 8 & 8 & 84 \\
EP4 & 0 & 11 & 8 & 81 \\
EP5 & 0 & 14 & 8 & 78 \\
EP6 & 0 & 20 & 8 & 72 \\
ES1 & 2 & 8 & 8 & 82 \\
ES2 & 5 & 8 & 8 & 77 \\
ES3 & 8 & 8 & 8 & 74 \\
ES4 & 11 & 8 & 8 & 73 \\
ES5 & 14 & 8 & 8 & 70 \\
ES6 & 20 & 8 & 8 & 64 \\
\hline
\end{tabular}

\subsection{Characterization Techniques}

The X-ray diffraction was carried out by a Shimadzu XRD 6100 diffractometer equipped with a Cu X-ray tube (Faculty of sciences, Oujda, Morocco), operating at $40 \mathrm{kV}$ and $30 \mathrm{~mA}$, in the range $2^{\circ}-70^{\circ} 2 \theta$. The infrared analysis was obtained using a Fourier transform spectrometer (FT/IR-4700, JASCO, Faculty of sciences, Oujda, Morocco), ATR mode (attenuated total reflectance), equipped with a DLaTGS detector and Peltier temperature control (Faculty of sciences, Oujda, Morocco). Rapid $10 \mathrm{~Hz}$ scan with a resolution of $0.4 \mathrm{~cm}^{-1}$ have acquired in a wavelength range of $400-4000 \mathrm{~cm}^{-1}$. Raman and Infrared (FTIR) analysis was performed at the Spectrometry Laboratory (CNRST, Rabat, Morocco), using the Vertex 70 Bruker apparatus equipped with an MCT detector with a resolution of $0.5 \mathrm{~cm}^{-1}$. The spectral range from 4000 to $70 \mathrm{~cm}^{-1}$. The $\mathrm{pH}$ was measured by a 920 Benchtop precision $\mathrm{pH}$ meter (Faculty of sciences, Oujda, Morocco). The Scanning Electron Microscopy (SEM) was carried out at the Scientific Research National Center (CNRST, Rabat, Morocco), with a resolution of $3.5 \mathrm{~nm}$ coupled with an EDX microanalysis of $133 \mathrm{eV}$ resolution. The TESTWELL device with a speed of $1 \mathrm{~mm} / \mathrm{min}$ obtained the compressive strength analysis. The thermal analysis was carried out using thermogravimetry (TGA) and differential scanning calorimetry (DSC) by heating the samples from 20 to $1000{ }^{\circ} \mathrm{C}$ at a uniform temperature ratio of $10^{\circ} \mathrm{C} / \mathrm{min}$. 


\section{Results and Discussion}

\subsection{Characterization of Raw Materials}

The physical properties of raw bentonite are shown in Table 2. Bentonite studied is classified as fatty clays $(\mathrm{CH})$ according to the Unified Soil Classification System (USCS). The particle size analysis by sedimentometry shows that this bentonite consists of $48.7 \%$ sandy fraction, $33.8 \%$ clay fraction and $17.8 \%$ silt. The geotechnical analysis is obtained according to the ASTM D4318 and ASTM D6913. The liquid limit of bentonite is measured using the Casagrande apparatus, and the particle size distribution for the fraction less than $80 \mu \mathrm{m}$ is obtained using the hydrometer method (Table 2).

The XRD analysis shows the occurrence of Ca-montmorillonite (Ca-Mt), Na-montmorillonite (Na-Mt), Na-feldspar (NaF), K-feldspar (KF) and Anorthite (Pl) (Figure 1). The chemicals composition of raw bentonite, phosphogypsum and black steel slag are presented in Table 3 [42,43]. The grains of bentonite show a "cornflake" or "oak leaf" morphology typical and representative of montmorillonite, associated with feldspars (Figure 2A). Lime XRD analysis reveals the presence of $\mathrm{CaO}, \mathrm{MgO}$ and $\mathrm{Ca}(\mathrm{OH})_{2}$ [31]. The steel slag consists of calcium ferrite $\left(\mathrm{CaFe}_{2} \mathrm{O}_{4}\right)$, calcium dis-silicate $\left(\mathrm{Ca}_{2} \mathrm{SiO}_{4}\right)$ srebrodoskite $\left(\mathrm{Ca}_{2} \mathrm{Fe}_{2} \mathrm{O}_{5}\right)$, fayalite $\left(\mathrm{Fe}_{2} \mathrm{SiO}_{4}\right)$, quartz $\left(\mathrm{SiO}_{2}\right)$, lime $(\mathrm{CaO})$, dolomite $\left(\mathrm{CaMg}\left(\mathrm{CO}_{3}\right)_{2}\right)$ and brownmillerite $\left(\mathrm{Ca}_{2}(\mathrm{Al}, \mathrm{Fe})_{2} \mathrm{O}_{5}\right)$ (Figure 1). The slag grains show pores with a diameter of $1.7-2.25 \mu \mathrm{m}$ (Figure 2C). The Phosphogypsum used in this study contains gypsum $\left(\mathrm{CaSO}_{4} \cdot 2 \mathrm{H}_{2} \mathrm{O}\right)$, bassanite $\left(\mathrm{CaSO}_{4} \cdot 1 / 2 \mathrm{H}_{2} \mathrm{O}\right)$ and anhydrite $\left(\mathrm{CaSO}_{4}\right)$ [31]. The hazardous trace elements $(\mathrm{Cd}, \mathrm{Se}, \mathrm{Cr}$ etc.) containing in Moroccan PG and Ss leachates were studied, respectively, by Sebbar et al. [44] and Hassoune et al. [45] (Table 4).

Table 2. Physical properties of raw bentonite.

\begin{tabular}{|c|c|c|c|c|c|c|c|}
\hline Clay & $\begin{array}{l}\text { Liquid } \\
\text { Limit \% }\end{array}$ & $\begin{array}{l}\text { Plasiticity } \\
\text { Limit \% }\end{array}$ & $\begin{array}{l}\text { Plasticity } \\
\text { Index } \\
\text { (PI) }\end{array}$ & $\begin{array}{c}\text { Clay } \\
(<0.005 \mathrm{~mm}) \\
\% \\
\end{array}$ & $\begin{array}{c}\text { Silt } \\
(0.005-0.075 \mathrm{~mm}) \\
\% \\
\end{array}$ & $\begin{array}{c}\text { Sand } \\
(0.075-2 \mathrm{~mm}) \\
\% \\
\end{array}$ & $\mathrm{pH}_{0}$ \\
\hline Bentonite & 103 & 30.5 & 72.5 & 33.8 & 17.8 & 48.7 & 8.72 \\
\hline
\end{tabular}

Table 3. Chemical analysis of raw materials.

\begin{tabular}{|c|c|c|c|c|c|c|c|c|c|c|c|c|}
\hline \multirow{2}{*}{ Compounds } & \multicolumn{12}{|c|}{ Chemical Composition \% in Mass } \\
\hline & $\mathrm{SiO}_{3}$ & $\mathrm{Al}_{2} \mathrm{O}_{3}$ & $\mathrm{Fe}_{2} \mathrm{O}_{3}$ & $\mathrm{CaO}$ & $\mathrm{MgO}$ & $\mathrm{SO}_{3}$ & $\mathrm{~K}_{2} \mathrm{O}$ & $\mathrm{TiO}_{2}$ & $\mathrm{MnO}$ & $\mathrm{Na}_{2} \mathrm{O}$ & $\mathrm{P}_{2} \mathrm{O}_{5}$ & $\mathrm{Cr}_{2} \mathrm{O}_{3}$ \\
\hline Bentonite & 59.9 & 24.4 & 3.00 & 1.11 & 2.57 & - & 0.69 & 0.20 & 0.01 & 2.20 & 0.03 & - \\
\hline $\begin{array}{c}\text { Phosphogypsum } \\
\text { [42] }\end{array}$ & 9.50 & 2.80 & 0.90 & 30.5 & 0.30 & 42.5 & - & - & - & - & 0.50 & - \\
\hline $\begin{array}{c}\text { Black Steel slag } \\
{[43]}\end{array}$ & 12.8 & 5.04 & 31.9 & 36.5 & 3.26 & 0.31 & - & 0.41 & 5.90 & - & 0.50 & 2.15 \\
\hline
\end{tabular}

Table 4. Hazardous trace elements in phosphogypsum (PG) and steel slag (Ss) leachates.

\begin{tabular}{ccccccccccc}
\hline \multirow{2}{*}{ Leachate } & \multicolumn{10}{c}{ Chemical Elements (ppm) } \\
\cline { 2 - 11 } & $\mathbf{Z n}$ & $\mathbf{N i}$ & $\mathbf{F e}$ & $\mathbf{C u}$ & $\mathbf{C d}$ & $\mathbf{P b}$ & $\mathbf{S e}$ & $\mathbf{A s}$ & $\mathbf{C r}$ \\
\hline Leachate of Ss [44] & $<0.005$ & $<0.003$ & $<0.004$ & $<0.005$ & $<0.003$ & $<0.01$ & $<0.0015$ & $<0.00005$ & $<0.005$ \\
Leachate of PG [45] & - & 0.125 & - & 0.496 & 1.558 & 0.021 & 0.017 & 0.074 & - \\
\hline
\end{tabular}




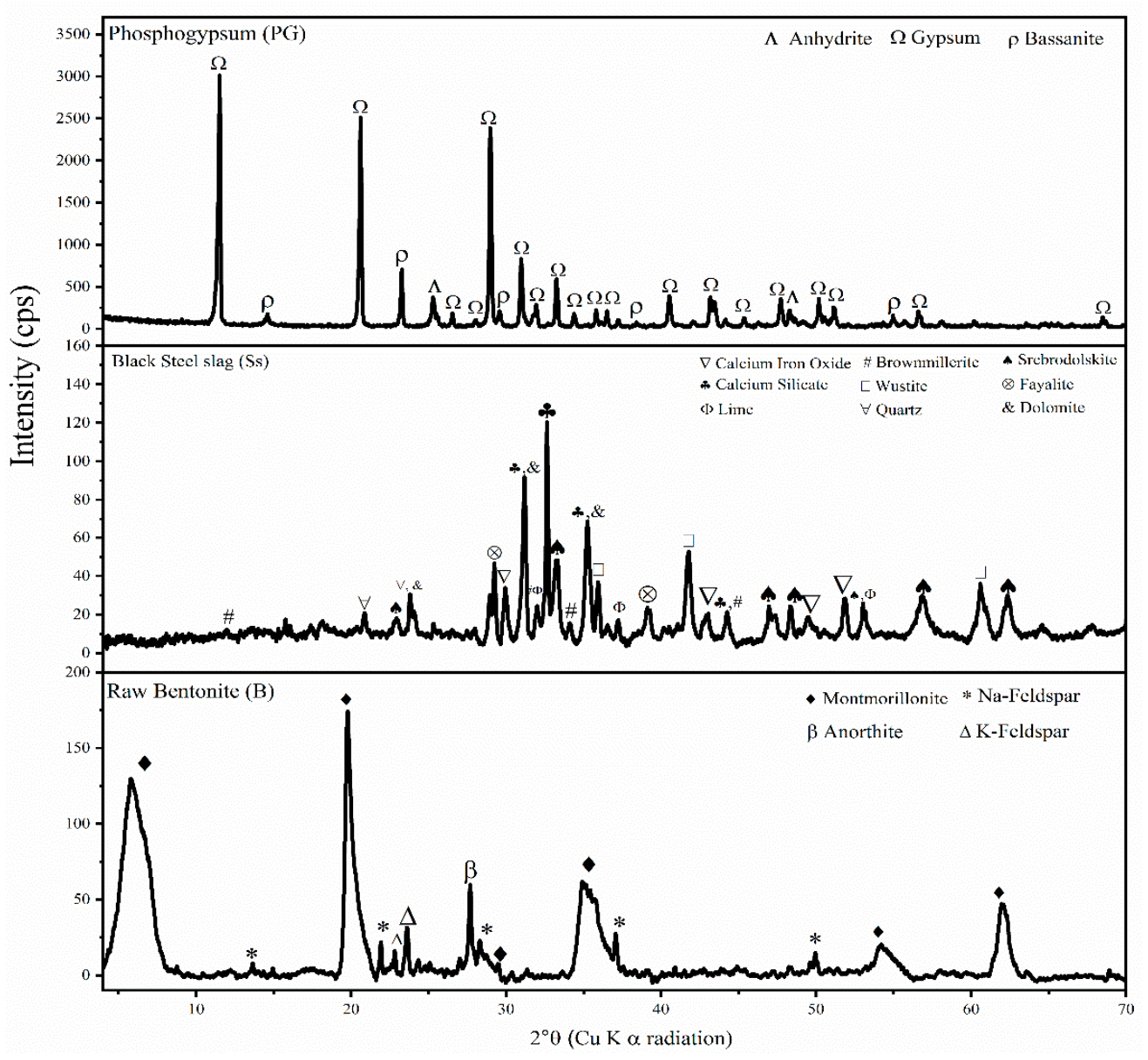

Figure 1. XRD patterns of phosphogypsum, steel slag, and raw bentonite.
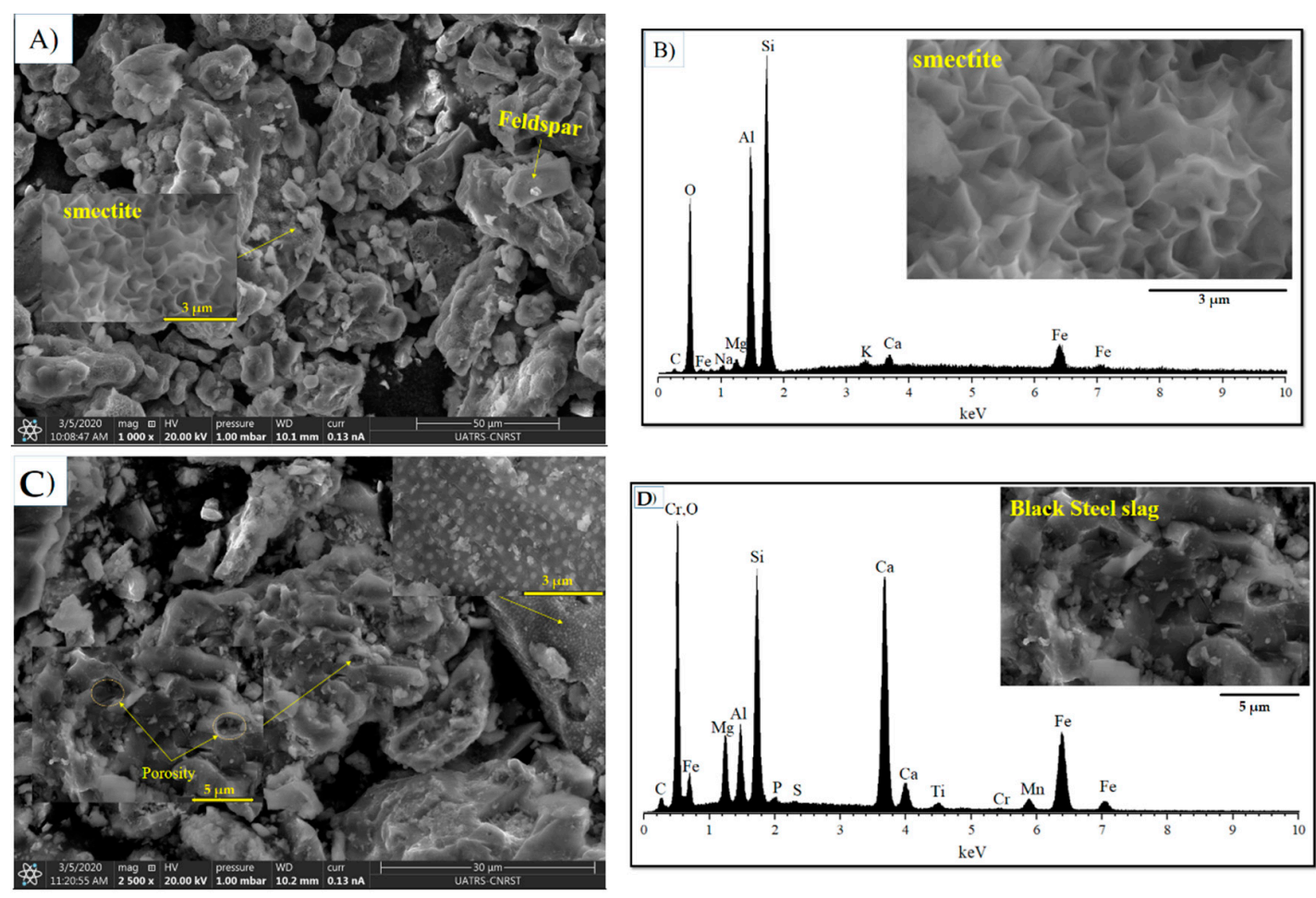

Figure 2. SEM and Energy-dispersive X-ray spectroscopy (EDX) images of raw material. (A,B) raw bentonite and (C,D) black steel slag. 


\subsection{Compressive Uniaxial Strength}

Figure 3A compares the uniaxial compressive strengths of the bentonite-lime mixture specimens after 15 and 28 days of hydration. The histograms corresponding to the two periods of the setting are similar. The optimal value is $0.97 \mathrm{MPa}$ for the EL mixture, corresponding to the maximum compressive strength, which is obtained when $8 \%$ of lime is added to the mixture (EL3). When increasing the amount of lime added, the compression strength increases. This result can be explained by the fact that the concentration of $\mathrm{Ca}^{2+}$ increases and the formation of $\mathrm{C}-\mathrm{S}-\mathrm{H}$ phase becomes more important due to the occurrence of pozzolanic reactions. From 15 to 28 days the amount of C-S-H increases, which is consistent with the increase in mechanical strength. Similar results are obtained by Manzano et al. [46]. In addition, they also showed that the longer the chains of the CSH silicate gel, the better the mechanical properties.

The addition of PG to the bentonite $+8 \%$ lime mixture increases the compressive uniaxial strength. The maximum value is obtained by adding $8 \%$ of PG (Figure 3B), which is in agreement with the results obtained by Oumnih and al. [30]. Using more than 8\% of PG, there is a remarkable drop in mechanical strength. Excess PG increases the acidity of the mixture, making the chains of the C-S-H gel and the hydrates formed less stable, explaining the observed decrease in compressive strength. The sulfate released from PG is consumed by the reaction between the aluminate hydrated gel and calcium cation to produce ettringite, thereby increasing the mechanical properties of the specimens.
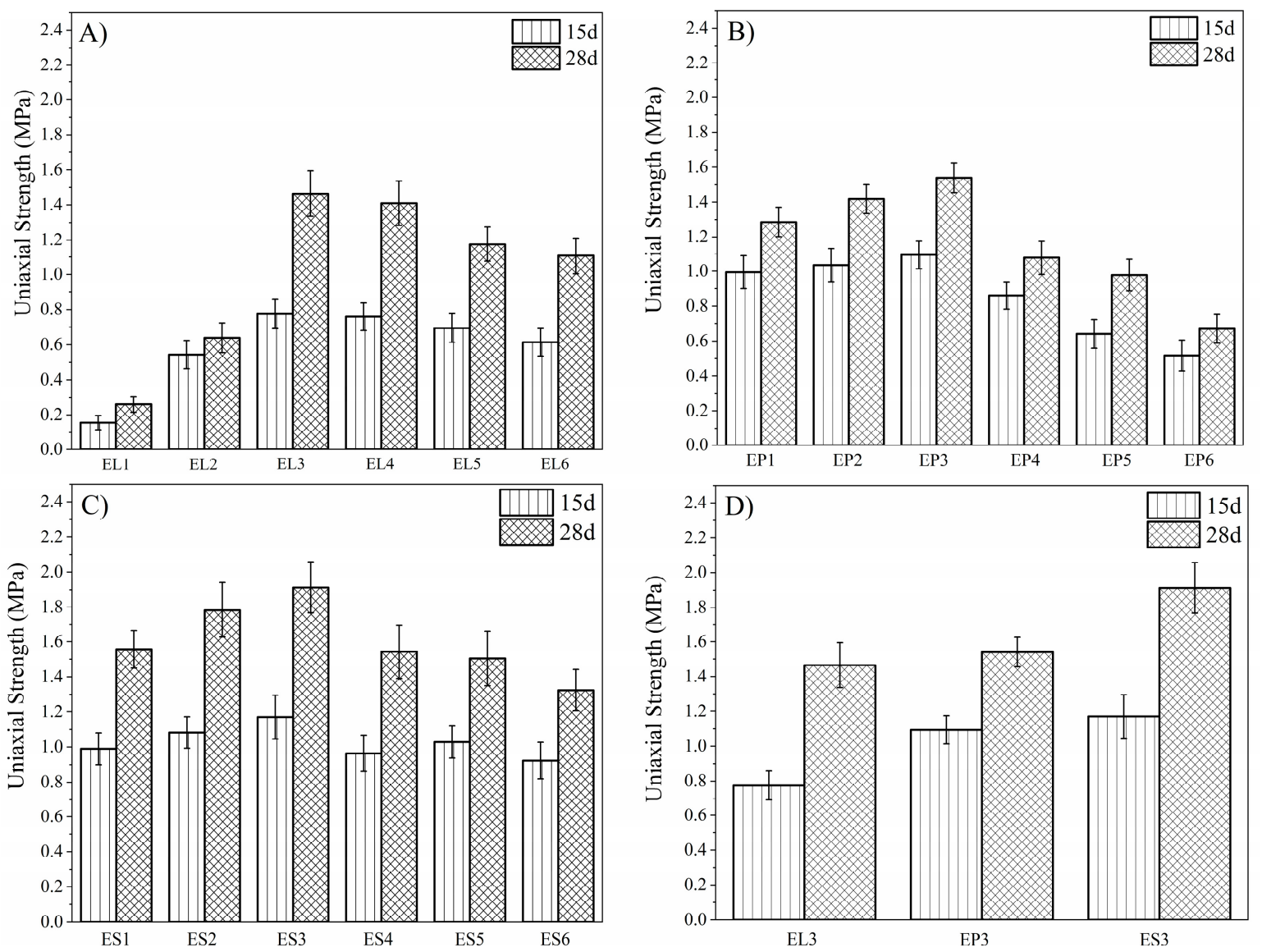

Figure 3. Compressive uniaxial strength of (A) bentonite + lime; (B) bentonite + lime + PG; (C) Bentonite + lime + PG + Ss after 15 and 28 days of hydration (D) Comparison between EL3 (B + 8\%L), EP3 (B + $8 \% \mathrm{~L}+8 \% \mathrm{PG})$ and $\mathrm{ES} 3(\mathrm{~B}+8 \% \mathrm{~L}+8 \% \mathrm{PG}+8 \% \mathrm{Ss})$.

The addition of black steel slag to the bentonite $+8 \%$ lime $+8 \%$ PG mixture increases the uniaxial compressive strength of the specimen's test (Figure 3C). The optimum value is $1.91 \mathrm{MPa}$ after 28 days of 
hydration for the ES3 mixture. It's obtained when adding $8 \%$ of black steel slag to the mixture B $+8 \% \mathrm{~L}$ $+8 \%$ PG. From 15 days to 28 days of hydration. The compression increases by $0.6 \mathrm{MPa}$ probably due to the presence of hydraulic phases such as $\mathrm{Ca}_{2} \mathrm{SiO}_{4}, \mathrm{Ca}_{2} \mathrm{Fe}_{2} \mathrm{O}_{5}$ and $\mathrm{Fe}_{2} \mathrm{SiO}_{4}$ in the slag. These hydraulic phases may contribute to the setting of the cement paste. After the flocculation of the clay minerals, aggregates can form around the coarse grains. This releases the surface of the bentonite and allows its direct contact with the lime which activates the pozzolanic reactions. Similarly, slags, being alkaline, may increase intake by neutralizing the residual acidity of PG. The Figure 3D showed comparison between EL3 $(\mathrm{B}+8 \% \mathrm{~L})$, EP3 (B + 8\% + 8\% PG) and ES3 (B + 8\%L + 8\% PG + 8\%Ss).

\subsection{Kinetic Study by XRD}

Figure $4 \mathrm{~A}$ shows the evolution of the $\mathrm{pH}$ of the mixtures EL3, EP3 and ES3 over time. Figure 4B-D) indicates the evolution of the mineralogical composition of the mixtures EL3, EP3 and ES3.

The initial $\mathrm{pH}$ of the leaching solutions of the mixtures is high $(\mathrm{pH}=12.5)$ due to the dissolution of calcium hydroxide $\left(\mathrm{Ca}(\mathrm{OH})_{2}\right)$ in water. It is attested by the decrease of the intensities of the $\mathrm{Ca}(\mathrm{OH})_{2}$ peak $(\mathrm{d}=2.6 \AA)$ of the mixings EL3, EP3 and ES3.

The mixture EL3 (i.e., $92 \%$ bentonite and $8 \%$ of lime, soaked in water; Figure 4B), shows the presence of Ca-montmorillonite (Ca-Mt), Na-montmorillonite (Na-Mt), Na-feldspar (NaF) and K-feldspar (KF), lime $(\mathrm{L})$, Anorthite $(\mathrm{Pl})$, periclase $(\mathrm{P})$, and calcium hydroxide $(\mathrm{CH})$. In presence of water $(\mathrm{W} / \mathrm{s}=46 \%)$, bentonite grains (Na-Mt and $\mathrm{Ca}-\mathrm{Mt}$ ) consolidate by coagulation aggregation and become denser [47]. The $\mathrm{pH}$ of the leach solution decreases slightly over time due to the consumption of $\mathrm{OH}^{-}$ions released by the lime during pozzolanic reactions. The $\mathrm{pH}$ decreases from $\sim 12$ to 11.3 after 7 days of setting.

After seven days of hydration of the EL3 mixture, calcite $\left(\mathrm{CaCO}_{3}\right)$ is formed and showed by the appearance of the characteristic peak at $d=3.03 \AA$. The formation of calcite can be explained by the neo-carbonation of lime according to the following reaction:

$$
\mathrm{Ca}(\mathrm{OH})_{2}+\mathrm{CO}_{2} \rightarrow \mathrm{CaCO}_{3}+\mathrm{H}_{2} \mathrm{O}
$$

After 28 days of hydration of the mixture EL3, the formation of hydrated calcium silicate (C-S-H) occurs at $\mathrm{d}=3.08 \AA$, due to the alteration of sodium and calcium bentonite by $\mathrm{Ca}^{2+}$ and $\mathrm{OH}^{-}$ ions released by lime in intra-granular solutions. The formation of $\mathrm{C}-\mathrm{S}-\mathrm{H}$ consumes the $\mathrm{OH}^{-}$ions, which causes a decrease in $\mathrm{pH}$ values.

Ettringite $\left(\mathrm{Ca}_{6} \mathrm{Al}_{2}\left(\mathrm{SO}_{4}\right)_{3}(\mathrm{OH})_{12} \cdot 26 \mathrm{H}_{2} \mathrm{O}\right)$ appears at $\mathrm{d}=5.61 \AA$, is formed after 3 days of hydration of the mixtures EP3 and ES3 containing PG and PG + Ss, respectively (Figure 4B,C). Ettringite crystals may accelerate the hydration of $\mathrm{C}-\mathrm{S}-\mathrm{H}$ phases, increase their compressive strength, reduce the setting time, yield strength, and plastic viscosity of the mixtures [48].

After seven days of setting, the $\mathrm{pH}$ of the leachate solution of the EP3 specimen drops to 10.7 (Figure 4A) and the C-S-H phases appear (Figure 4B). The occurrence of C-S-H gel which consumes the hydroxide ions is accelerated by the presence of PG. The drop in $\mathrm{pH}$ could also be attributed to the release of residual acidity over time. After 28 days, the $\mathrm{pH}$ of the EP3 solution stabilizes at 9.48.

The addition of $8 \%$ of black steel slag to the mixture PG-bentonite-lime does not reflect any change in the XRD spectra of the EP3 mixture, and the evolution of the $\mathrm{pH}$ of the leached solutions gives the same variation as the EP3 mixture. 
A)

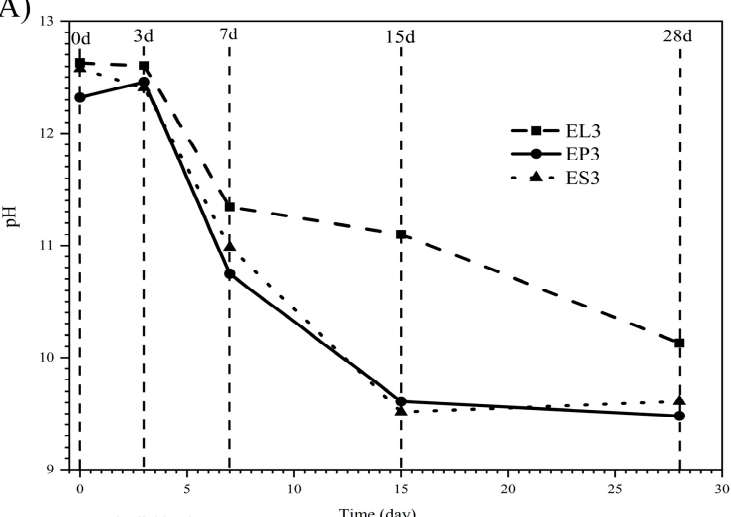

C)

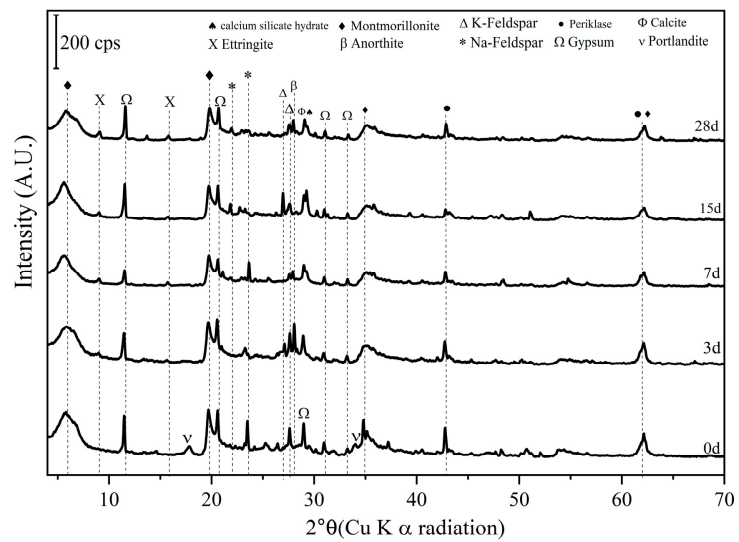

B)

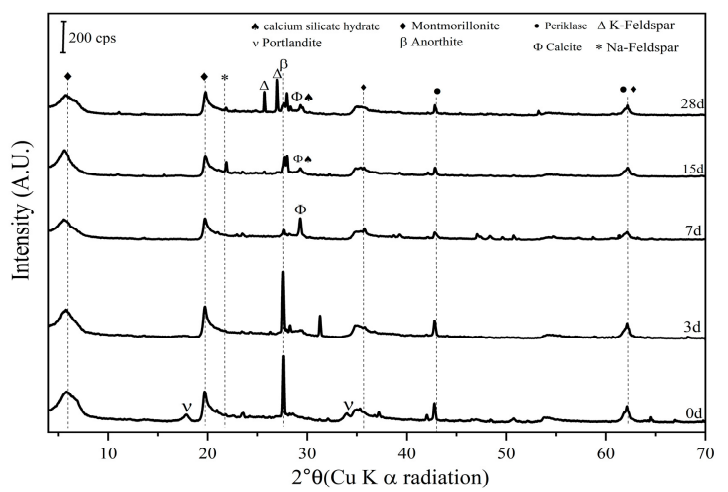

D)

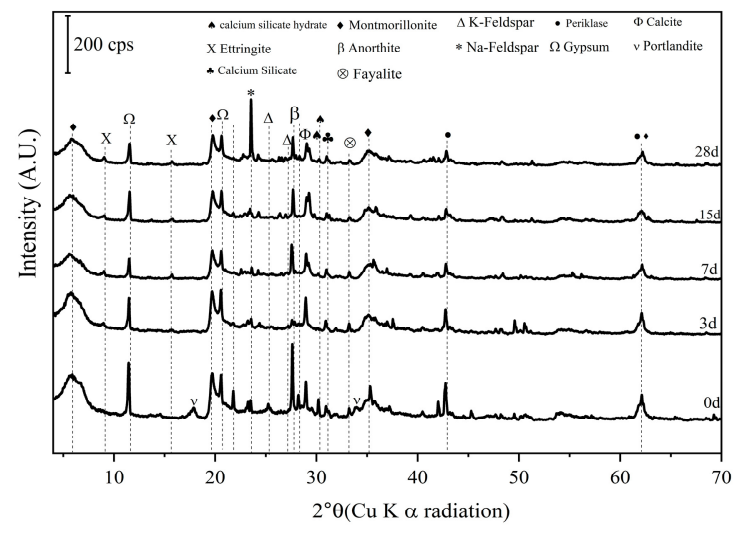

Figure 4. Evolution of pH of EL3, EP3 and ES3 mixtures (A); XRD spectra of EL3 (B), EP3 (C) and ES3 (D).

\subsection{Infrared and Raman Results}

Figure 5A shows the infrared spectra of raw bentonite and samples EL3, EP3 and ES3. The absorption band at $3700-3600 \mathrm{~cm}^{-1}$ is due to stretching of the $\mathrm{OH}$ band of water adsorbed [20]. The two peaks observed at 1622 and $1539 \mathrm{~cm}^{-1}$ are related to the vibration of $\mathrm{OH}$ of water adsorbed in the interlayer space of Na-montmorillonite or Ca-montmorillonite and PG hydration water. The band at $1107 \mathrm{~cm}^{-1}$ is attributed to the bending vibrations of the $\mathrm{Si}-\mathrm{O}$ band. The Al-Al-OH bending vibrations are observed at $918 \mathrm{~cm}^{-1}$, the $\mathrm{Al}-\mathrm{O}-\mathrm{Si}$ deformation vibrations are at $\sim 520 \mathrm{~cm}^{-1}$, and the $\mathrm{Si}-\mathrm{O}-\mathrm{Si}$ deformation vibrations are at $467 \mathrm{~cm}^{-1}$ [49].

When $8 \%$ of PG is added, a peak at $3411 \mathrm{~cm}^{-1}$ appears which is attributed to the symmetrical and asymmetric stretching of the $\mathrm{OH}$ bond of hydrated water in the gypsum molecule $\mathrm{CaSO}_{4} \cdot 2 \mathrm{H}_{2} \mathrm{O}$ [29]. Stretching and bending vibrations of $\mathrm{SO}_{4}$ of PG are also observed at $1102 \mathrm{~cm}^{-1}$ and $669 \mathrm{~cm}^{-1}$, respectively. The most intense band at $992 \mathrm{~cm}^{-1}$ is attributed to asymmetric $\mathrm{Si}-\mathrm{O}-\mathrm{Si}$ stretching and the band at $518 \mathrm{~cm}^{-1}$ is due to the vibrational mode of $\mathrm{Si}-\mathrm{O}-\mathrm{Si}$ bending in calcium silicate $\left(\mathrm{Ca}_{2} \mathrm{SiO}_{4}\right)$ found in steel slag [50].

Figure 5B shows the Raman spectra for raw bentonite and mixtures EL3, EP3 and ES3. The peak at $1086 \mathrm{~cm}^{-1}$ is due to $\mathrm{Si}-\mathrm{O}^{*}$ bond stretching vibration of $\mathrm{Si}_{2} \mathrm{O}_{5}{ }^{2-}$ of the $\mathrm{Si}-\mathrm{O}-\mathrm{Si}\left(\mathrm{Q}^{4}\right)$ bond in $\mathrm{SiO}_{2}[51-53]$. This peak disappears on the spectra EL3, EP3 and ES3 due to the destabilization of the siliceous structure by lime. C-S-H gel is formed in EL3, EP3 and ES3 mixtures change the environment of tetrahedra $\left[\mathrm{SiO}_{4}\right]^{4-}$ and give the peak labeled $\mathrm{Q}^{1}$ (Figure $5 \mathrm{~B}$ ). A peak at $702 \mathrm{~cm}^{-1}$ is observed for mixtures EL3, EP3 and ES3, attributed to the elongations of the $\mathrm{Si}-\mathrm{O}^{*}$ bond $\left(\mathrm{Q}^{1}\right)$ [54]. 

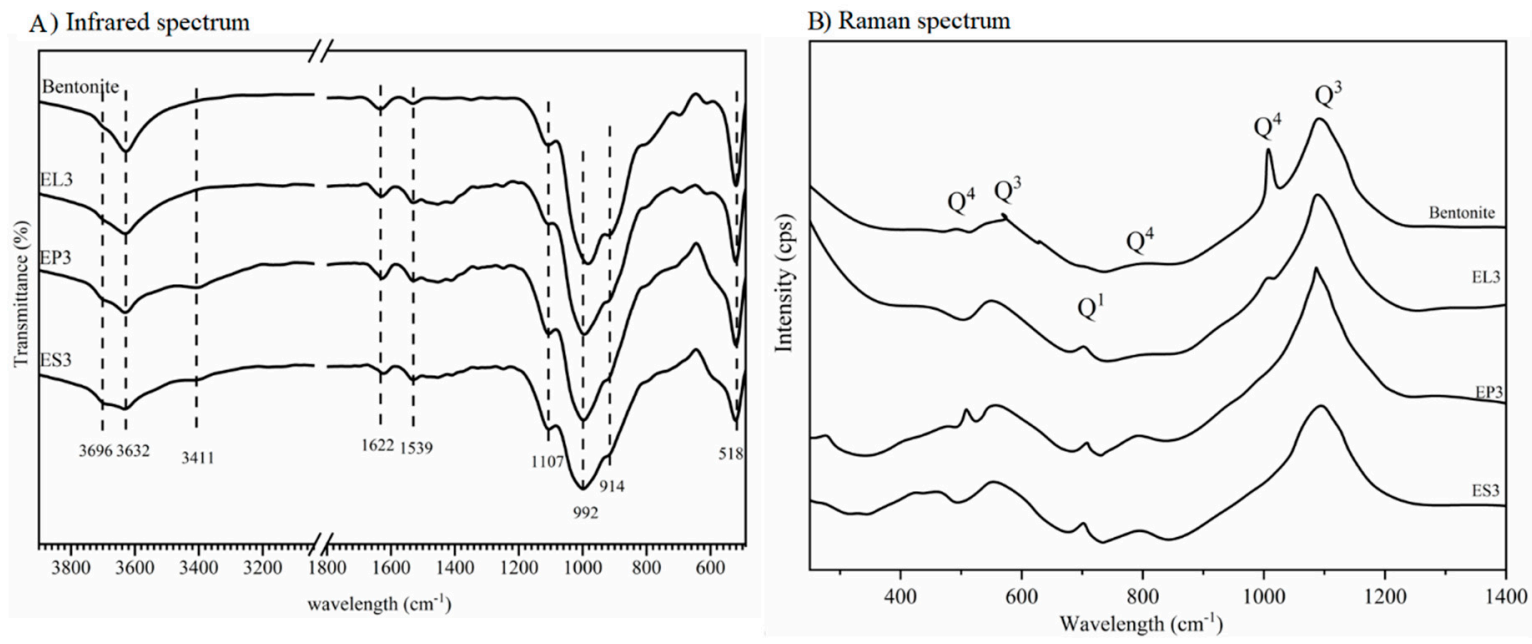

Figure 5. Infrared (A) and Raman (B) spectra of raw bentonite and El3, EP3 and ES3 mixtures.

The mechanism of C-S-H chains formation involves three steps according to Monnin [55]:

- $\quad$ Step 1: formation of $\mathrm{Q}^{3}$ tetrahedra by an attack of hydroxyl ions on $\mathrm{Q}^{4}$ tetrahedra:

$$
2 \mathrm{SiO}+\mathrm{OH}^{-} \rightarrow \mathrm{SiO}_{5 / 2}{ }^{-}+\mathrm{SiO}_{5 / 2} \mathrm{H}
$$

Breaking a siloxane bond induces the formation of two $\mathrm{Q}^{3}$ tetrahedra. Depending on the $\mathrm{pH}$, the $\mathrm{Q}^{3}$ sites are either ionized or protonated:

$$
\mathrm{SiO}_{5 / 2}{ }^{-}+\mathrm{H}_{2} \mathrm{O}+\mathrm{SiO}_{5 / 2} \mathrm{H} \rightarrow \mathrm{OH}^{-}
$$

- Step 2: the dissolution of tetrahedra $\mathrm{Q}^{3}$ in the form of tetrahedra $\mathrm{Q}^{0}$ follows further cutting of siloxane bonds by hydroxyl ions:

$$
\mathrm{SiO}_{5 / 2}{ }^{-}+\mathrm{OH}^{-}+\frac{1}{2} \mathrm{H}_{2} \mathrm{O} \rightarrow \mathrm{H}_{2} \mathrm{SiO}_{4}{ }^{2-}
$$

- Step 3: the dissolved silica can diffuse into the interstitial solution and form with the alkalis and lime hydrated calcium silicates and/or hydrated calco-sodium silicates of type $\mathrm{Q}^{1}$ :

$$
\mathrm{H}_{2} \mathrm{SiO}_{4}{ }^{2-}+\mathrm{Ca}^{2+}+\mathrm{xH}_{2} \mathrm{O} \rightarrow \text { C-S-H }
$$

$$
\text { Or } 2 \mathrm{H}_{2} \mathrm{SiO}_{4}{ }^{2-}+\mathrm{Na}^{+}+\mathrm{Ca}^{2+}+\mathrm{xH}_{2} \mathrm{O} \rightarrow \text { C-S-N-H }
$$

Figure 6 summarizes the arrangement of tetrahedra $\left[\mathrm{SiO}_{4}\right]^{4-}$ in silicate structures and the corresponding peak type $\mathrm{Q}^{\mathrm{n}}$.

\subsection{Microstructure}

SEM observations of mixtures EL3 after 28 days of hydration (Figure 7A) shows the development of $\mathrm{C}-\mathrm{S}-\mathrm{H}$ gel around bentonite grains. The EP3 and ES3 mixtures rather display an elongated crystal of acicular shape corresponding to ettringite (Figure 7B,C). Ettringite is formed in the free spaces of the mixtures EP3 and ES3 and its presence decreases the porosity of the specimen block. Consequently, ettringite contributes to improving the cohesion between the particles of clays and therefore increases the mechanical strength. 
The particles of the black steel slag have modified the surface of the bodies (Figure 7C), allowing ettringite and $\mathrm{C}-\mathrm{S}-\mathrm{H}$ gel neoformation. The influence of chemical alteration may be attested by the presence of calcium di-silicate $\left(\mathrm{Ca}_{2} \mathrm{SiO}_{4}\right.$, belite) in steel slag. Belite, a major component of portland cement thar reacts with water to give $\mathrm{C}-\mathrm{S}-\mathrm{H}$ gel. The Figure 7D showed the Energy-dispersive X-ray spectroscopy (EDX) of EL3, EP3 and ES3 mextures.

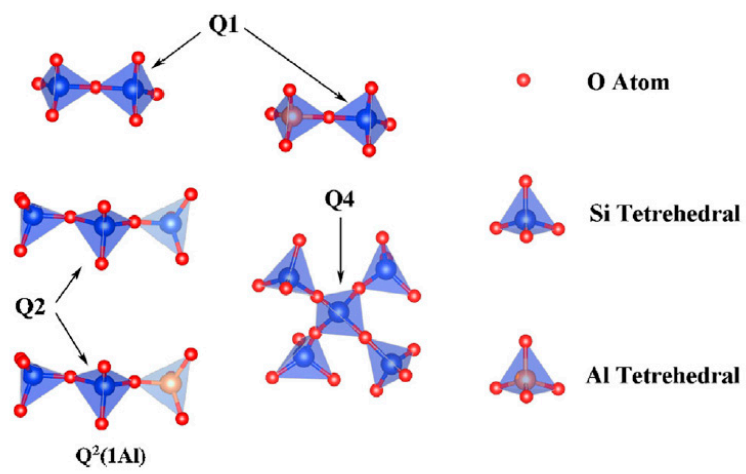

Figure 6. Schematic diagram of $\mathrm{Q}^{\mathrm{n}}$ in alumino-silicate structure.

A) EL3 (Bentonite+8\%L)

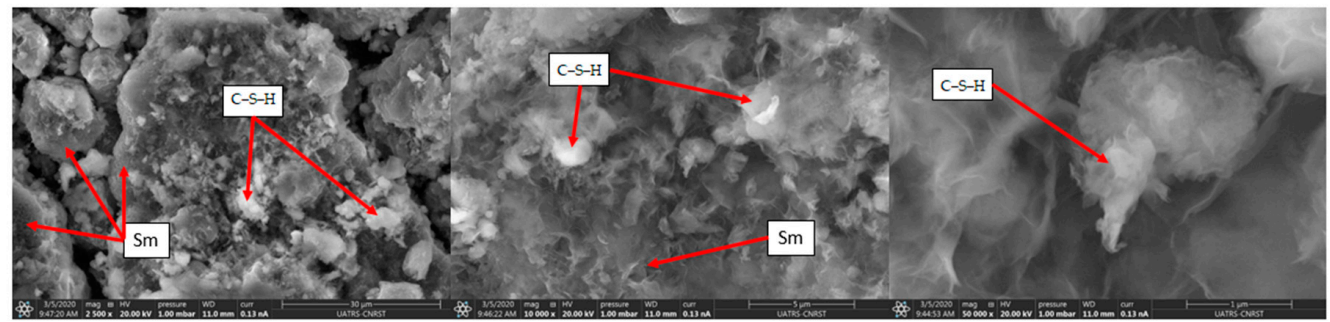

B) EP3 (Bentonite+8\%L+8\%PG)

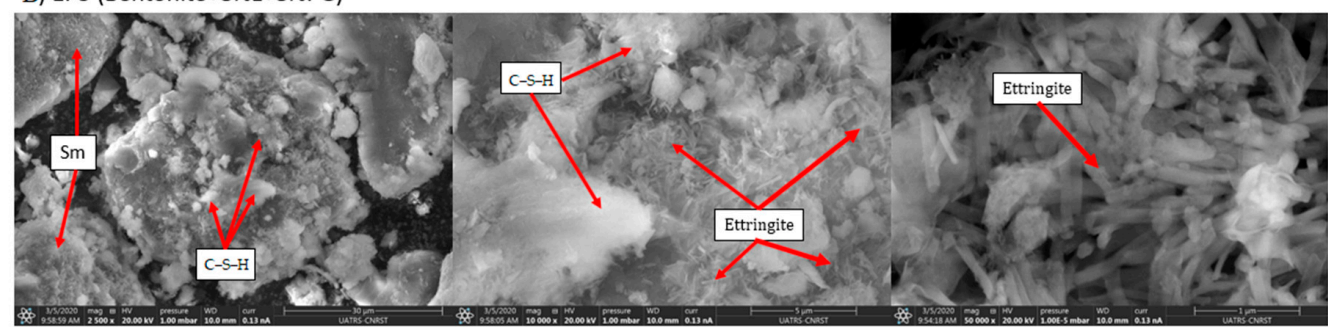

C) ES3 (Bentonite+8\%L+8\%PG+8\%Ss)

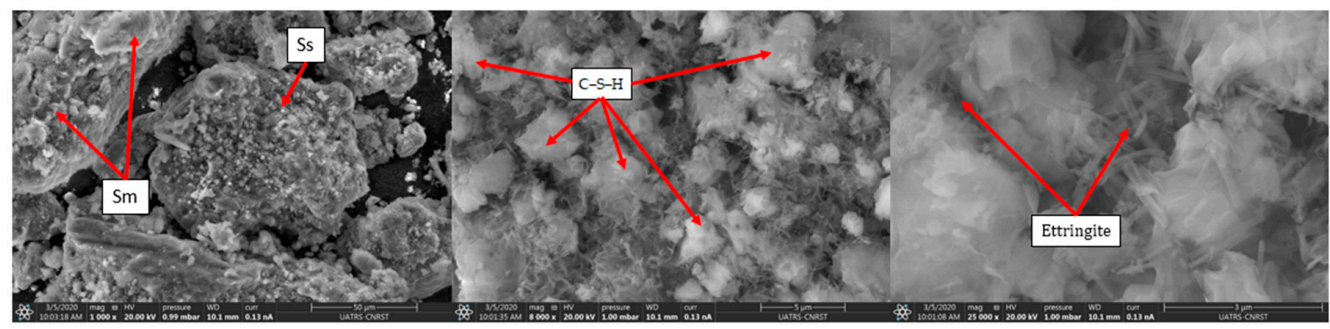

D)EDX microanalysis spectra

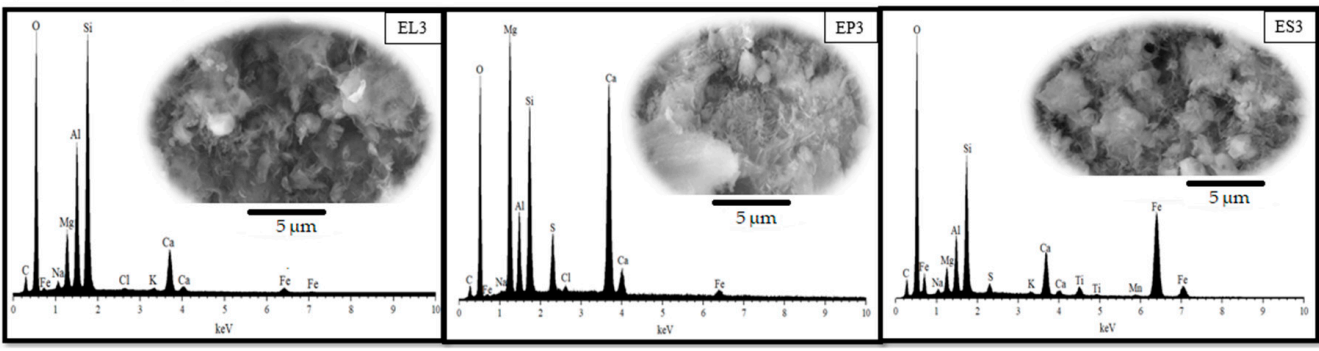

Figure 7. SEM images of (A) EL3, (B) EP3, (C) ES3 mixtures and (D) EDX spectra of EL3, EP3 and ES3. 


\subsection{DSC Analysis}

As shown in Figure 8, the DSC analysis of EL3 mixture showed four endothermic peaks associated with a loss of mass. The first weight loss that occurs between 85 and $156{ }^{\circ} \mathrm{C}$, is attributed to the water molecules adsorbed to the Ca-Mt or Na-Mt.

The addition of $8 \%$ of PG in EP3 and ES3 mixtures shows two small endothermic peaks at $128^{\circ} \mathrm{C}$ and $152{ }^{\circ} \mathrm{C}$, which the latter corresponds to a loss of water molecules from ettringite crystal in the samples [56]. The endothermic peak at $470-545{ }^{\circ} \mathrm{C}$ can be attributed to the decomposition of calcium hydroxide to the lime with the following reaction:

$$
\mathrm{Ca}(\mathrm{OH})_{2} \rightarrow \mathrm{CaO}+2 \mathrm{H}_{2} \mathrm{O}
$$

The fourth weight loss occurs at $650-800{ }^{\circ} \mathrm{C}$, which corresponds to the decomposition of calcite [56,57].

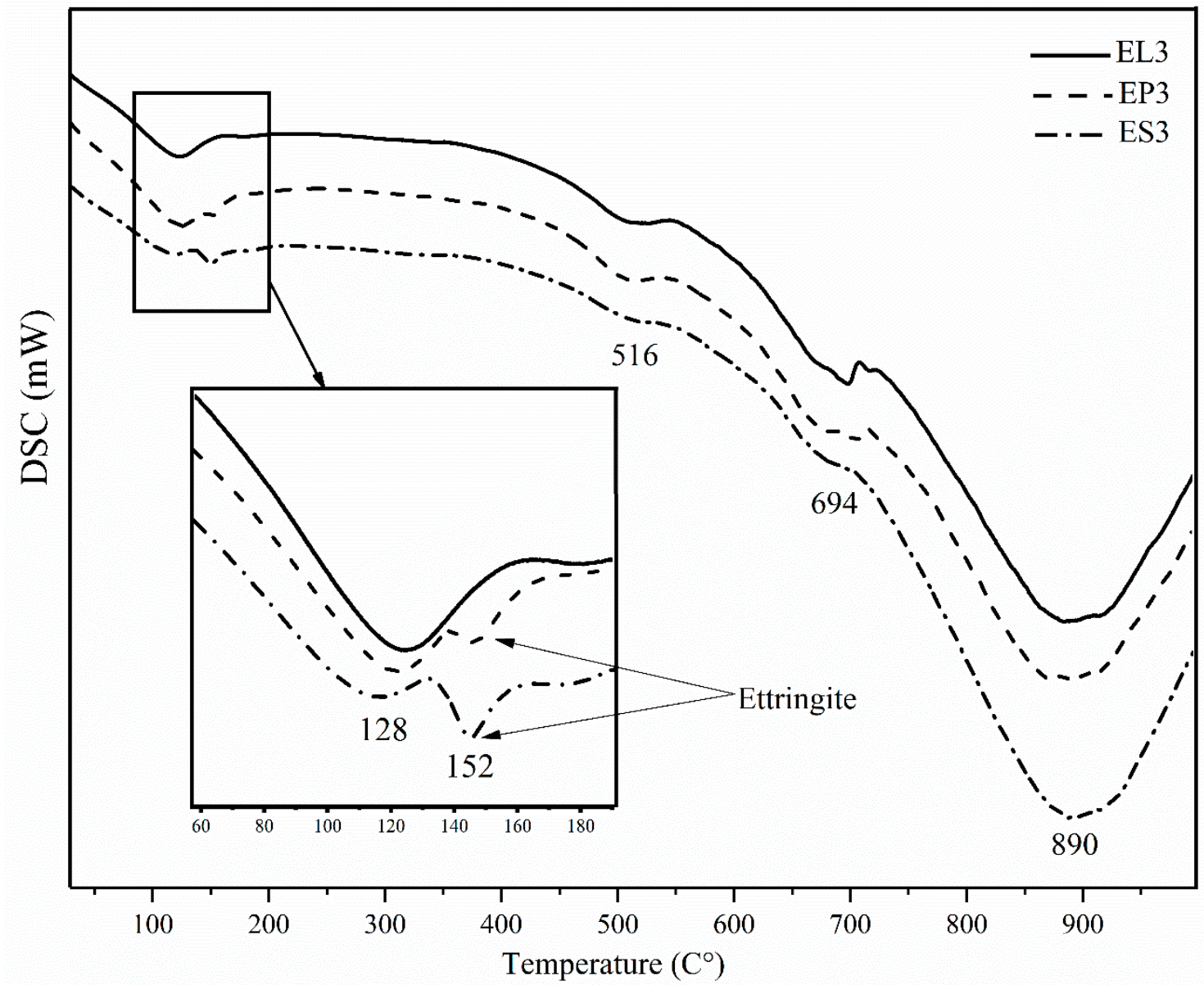

Figure 8. Differential scanning calorimetry (DSC) curves of EL3, EP3 and ES3 mixtures after 28 days of hydration.

\section{Conclusions}

In this paper, the industrial waste produced in Morocco, namely black steel slag (Ss) and phosphogypse (PG), was recovered by mixing it with bentonite (B) and lime (L) without any prior chemical treatment. The use of PG and black steel slag as additive raw materials in bentonite-lime mixture is valuable for environment-protecting and resource conservation. These wastes increase the mechanical properties of bentonite-lime mixtures. This enhancement promises to bring about new opportunities for using these wastes as an additive in concrete cement for building and road embankment construction. 
Microstructures and characterization of bentonite-lime, bentonite-lime-PG and bentonite-lime-PG-Ss were investigated. On the basis of the results obtained, the following conclusions are reached:

- The hydration kinetics of the bentonite-lime and bentonite-lime-PG mixtures are slow.

- The formation of calcium silicate hydrate $(\mathrm{C}-\mathrm{S}-\mathrm{H})$ increases the mechanical properties of bentonite-lime, bentonite-lime-PG and bentonite-lime-PG-Ss mixtures.

- The addition of PG alone to the bentonite-lime mixture allows the neo-formation of hydrated calcium silicate (C-S-H) and ettringite, which increases the compressive strength of the specimens.

- The microstructural analysis confirmed the formation of ettringite, which bonds the aggregates of the bentonite-lime-PG and bentonite-lime-PG-Ss mixtures.

- The addition of the black steel slag to the bentonite-lime-PG mixture accelerates the hydration kinetics and activates the pozzolanic reaction due to the presence of $\mathrm{C}_{2} \mathrm{~S}$ in the slag, and thus promoting the increase of the mechanical strength of the B-L-PG-Ss mixture.

- The compressive strength of hydrated BL, BL-PG and BL-PG-Ss mixtures increases from 15 to 28 days of curing. Furthermore, $8 \%$ of slag added to the B-L-PG mixture increase the mechanical compression of $0.6 \mathrm{MPa}$ after 28 days of hardening.

Author Contributions: Conceptualization: A.H., E.K.G. and M.E.O.; methodology: A.H., E.K.G. and M.E.O.; validation, A.H., E.K.G. and M.E.O.; formal analysis, A.H.; investigation, A.H.; writing-original draft preparation, A.H.; writing-review and editing, E.K.G., M.E.O., Y.T. and N.F.; supervision, E.K.G. and M.E.O.; project administration E.K.G. and M.E.O.; All authors have read and agreed to the published version of the manuscript.

Funding: This research received no external funding.

Acknowledgments: The authors would thank the SONASID company for the slag samples and the OCP company for the phosphogypsum samples. We thank also the Faculty of Sciences, Mohammed First University (Morocco) for its valuable technical support for the results achieved.

Conflicts of Interest: The authors declare no conflict of interest.

\section{References}

1. World Steel in Figures. World Steel Association ISBN 978-2-930069-87-6. $2016 . \quad$ Available online: https://www.worldsteel.org/en/dam/jcr:4f060d8b-3602-4ffe-9e87-7e93e0659449/Word+Steel+in+ -Figures+2016.pdf (accessed on 29 September 2020).

2. Rapport Financier Semestriel. Relation Actionnaires, SONASID. 2019. Available online: http://www.sonasid. ma/Finances/Rapports-annuels (accessed on 29 September 2020).

3. Chaurand, P.; Rose, J.; Briois, V.; Olivi, L.; Hazemann, J.L.; Proux, O.; Nzssif, V.; Susini, J.; Salom, M.; Bottero, J.Y. Environmental impacts of steel slag reused in road construction: A crystallographic and molecular (XANES) approach. J. Hazard. Mater. 2007, 139, 537-542. [CrossRef] [PubMed]

4. Nakase, K.; Matsui, A.; Kikuchi, N.; Miki, Y.; Kishimoto, Y.; Goto, I.; Nagasaka, T. Fundamental research on a rational steelmaking slag recycling system by phosphorus separation and collection. J. Manuf. Sci. Prod. 2013, 13, 39-45. [CrossRef]

5. Igarashi, T.; Herrera, P.S.; Uchiyama, H.; Miyamae, H.; Iyatomi, N.; Hashimoto, K.; Tabelin, C.B. The two-step neutralization ferrite-formation process for sustainable acid mine drainage treatment: Removal of copper, zinc and arsenic, and the influence of coexisting ions on ferritization. Sci. Total Environ. 2020, 715, 136877. [CrossRef] [PubMed]

6. Tabelin, C.B.; Igarashi, T.; Villacorte-Tabelin, M.; Park, I.; Opiso, E.M.; Ito, M.; Hiroyoshi, N. Arsenic, selenium, boron, lead, cadmium, copper, and zinc in naturally contaminated rocks: A review of their sources, modes of enrichment, mechanisms of release, and mitigation strategies. Sci. Total Environ. 2018, 645, 1522-1553. [CrossRef]

7. Tabelin, C.B.; Silwamba, M.; Paglinawan, F.C.; Mondejar, A.J.S.; Duc, H.G.; Resabal, V.J.; Opiso, E.M.; Igarashi, T.; Tomiyama, S.; Ito, M.; et al. Solid-phase partitioning and release-retention mechanisms of copper, lead, zinc and arsenic in soils impacted by artisanal and small-scale gold mining (ASGM) activities. Chemosphere 2020, 260, 127574. [CrossRef] 
8. Sarfo, P.; Das, A.; Wyss, G.; Young, C. Recovery of metal values from copper slag and reuse of residual secondary slag. Waste Manag. 2017, 70, 272-281. [CrossRef] [PubMed]

9. Sarfo, P.; Wyss, G.; Ma, G.; Das, A.; Young, C. Carbothermal reduction of copper smelter slag for recycling into pig iron and glass. Miner. Eng. 2017, 107, 8-19. [CrossRef]

10. Roychand, R.; Pramanik, B.K.; Zhang, G.; Setunge, S. Recycling steel slag from municipal wastewater treatment plants into concrete applications-A step towards circular economy. Resour. Conserv. Recycl. 2020, 152, 104533. [CrossRef]

11. Wang, Z.; He, X.; Li, J.; Qi, J.; Zhao, C.; Yang, G. Preparation of magnetic steel-slag particle electrode and its performance in a novel electrochemical reactor for oilfield wastewater advanced treatment. J. Ind. Eng. Chem. 2018, 58, 18-23. [CrossRef]

12. Barca, C.; Roche, N.; Troesch, S.; Andres, Y.; Chazarenc, F. Modelling hydrodynamics of horizontal flow steel slag filters designed to upgrade phosphorus removal in small wastewater treatment plants. J. Environ. Manag. 2018, 206, 349-356. [CrossRef]

13. Amuchi, M.; Abtahi, S.M.; Koosha, B.; Hejazi, S.M.; Sheikhzeinoddin, H. Reinforcement of steel-slag asphalt concrete using polypropylene fibers. J. Ind. Text. 2015, 44, 526-541. [CrossRef]

14. Gonçalves, D.R.; Fontes, W.C.; Mendes, J.C.; Silva, G.J.; Peixoto, R.A. Evaluation of the economic feasibility of a processing plant for steelmaking slag. Waste Manag. Res. 2016, 34, 107-112. [CrossRef] [PubMed]

15. Kang, G.; Cikmit, A.A.; Tsuchida, T.; Honda, H.; Kim, Y.S. Strength development and microstructural characteristics of soft dredged clay stabilized with basic oxygen furnace steel slag. Constr. Build. Mater. 2019, 203, 501-513. [CrossRef]

16. Cao, L.; Shen, W.; Huang, J.; Yang, Y.; Zhang, D.; Huang, X.; Jiel, Z.; Ji, X. Process to utilize crushed steel slag in cement industry directly: Multi-phased clinker sintering technology. J. Clean. Prod. 2019, 217, 520-529. [CrossRef]

17. Zhang, X.; Zhao, S.; Liu, Z.; Wang, F. Utilization of steel slag in ultra-high performance concrete with enhanced eco-friendliness. Constr. Build. Mater. 2019, 214, 28-36. [CrossRef]

18. Zhang, Y.J.; Liu, L.C.; Xu, Y.; Wang, Y.C. A new alkali-activated steel slag-based cementitious material for photocatalytic degradation of organic pollutant from waste water. J. Hazard. Mater. 2012, 209, 146-150. [CrossRef] [PubMed]

19. Huang, Y.; Qian, J.; Lu, L.; Zhang, W.; Wang, S.; Wang, W.; Cheng, X. Phosphogypsum as a component of calcium sulfoaluminate cement: Hazardous elements immobilization, radioactivity and performances. J. Clean. Prod. 2020, 248, 119287. [CrossRef]

20. Liu, L.; Zhou, A.; Deng, Y.; Cui, Y.; Yu, Z.; Yu, C. Strength performance of cement/slag-based stabilized soft clays. Constr. Build. Mater. 2019, 211,909-918. [CrossRef]

21. Croft, J.B. The influence of soil mineralogical composition on cement stabilization. Geotechnique 1967, 17, 119-135. [CrossRef]

22. Tayibi, H.; Choura, M.; López, F.A.; Alguacil, F.J.; López-Delgado, A. Environmental impact and management of phosphogypsum. J. Environ. Manag. 2009, 90, 2377-2386. [CrossRef]

23. Oumnih, S.; Gharibi, E.; Yousfi, E.B.; Bekkouch, N.; El Hammouti, K. Posphogypsum waste valorization by acid attack with the presence of metallic iron. J. Mater. Environ. Sci. 2017, 8, 338-344.

24. Tsioka, M.; Voudrias, E.A. Comparison of alternative management methods for phosphogypsum waste using life cycle analysis. J. Clean. Prod. 2020, 121386. [CrossRef]

25. Rutherford, P.M.; Dudas, M.J.; Arocena, J.M. Trace elements and fluoride in phosphogypsum leachates. Environ. Technol. 1995, 16, 343-354. [CrossRef]

26. Romero-Hermida, M.I.; FloreS-Alés, V.; Hurtado-Bermúdez, S.J.; Santos, A.; Esquivias, L. Environmental Impact of Phosphogypsum-Derived Building Materials. Int. J. Environ. Res. Public Health 2020, 17, 4248. [CrossRef] [PubMed]

27. Silva, M.V.; de Rezende, L.R.; dos Anjos Mascarenha, M.M.; de Oliveira, R.B. Phosphogypsum, tropical soil and cement mixtures for asphalt pavements under wet and dry environmental conditions. Resour. Conserv. Recycl. 2019, 144, 123-136. [CrossRef]

28. De Rezende, L.R.; Curado, T.D.S.; Silva, M.V.; Mascarenha, M.M.D.A.; Metogo, D.A.N.; Neto, M.P.C.; Bernucci, L.L.B. Laboratory study of phosphogypsum, stabilizers, and tropical soil mixtures. J. Mater. Civ. Eng. 2017, 29, 04016188. [CrossRef] 
29. Zeng, L.L.; Bian, X.; Zhao, L.; Wang, Y.J.; Hong, Z.S. Effect of phosphogypsum on physiochemical and mechanical behaviour of cement stabilized dredged soil from Fuzhou, China. Geomech. Energy Environ. 2020, 100195. [CrossRef]

30. Oumnih, S.; Gharibi, E.K.; Bekkouch, N.; Fagel, N.; Elhamouti, K.; El Ouahabi, M. Phosphogypsum waste as additives to lime stabilization of bentonite. Sustain. Environ. Res. 2019, 29, 35. [CrossRef]

31. Harrou, A.; Gharibi, E.; Nasri, H.; Fagel, N.; El Ouahabi, M. Physico-mechanical properties of phosphogypsum and black steel slag as aggregate for bentonite-lime based materials. Mater. Today Proc. 2020. [CrossRef]

32. Amrani, M.; Taha, Y.; Kchikach, A.; Benzaazoua, M.; Hakkou, R. Phosphogypsum recycling: New horizons for a more sustainable road material application. J. Build. Eng. 2020, 30, 101267. [CrossRef]

33. Değirmenci, N. Utilization of phosphogypsum as raw and calcined material in manufacturing of building products. Constr. Build. Mater. 2008, 22, 1857-1862. [CrossRef]

34. Ajam, L.; Ouezdou, M.B.; Felfoul, H.S.; El Mensi, R. Characterization of the Tunisian phosphogypsum and its valorization in clay bricks. Constr. Build. Mater. 2009, 23, 3240-3247. [CrossRef]

35. Rosales, J.; Pérez, S.M.; Cabrera, M.; Gázquez, M.J.; Bolivar, J.P.; de Brito, J.; Agrela, F. Treated phosphogypsum as an alternative set regulator and mineral addition in cement production. J. Clean. Prod. 2020, 244, 118752. [CrossRef]

36. Gu, K.; Chen, B. Loess stabilization using cement, waste phosphogypsum, fly ash and quicklime for self-compacting rammed earth construction. Constr. Build. Mater. 2020, 231, 117195. [CrossRef]

37. Romero-Hermida, M.I.; Borrero-López, A.M.; Alejandre, F.J.; Flores-Alésc, V.; Santosd, A.; Francob, J.M.; Esquiviasa, L. Phosphogypsum waste lime as a promising substitute of commercial limes: A rheological approach. Cem. Concr. Compos. 2019, 95, 205-216. [CrossRef]

38. Haque, M.A.; Chen, B.; Liu, Y.; Shah, S.F.A.; Ahmad, M.R. Improvement of physico-mechanical and microstructural properties of magnesium phosphate cement composites comprising with Phosphogypsum. J. Clean. Prod. 2020, 121268. [CrossRef]

39. Shen, W.; Liu, Y.; Wu, M.; Zhang, D.; Du, X.; Zhao, D.; Xu, G.; Zhang, B.; Xiong, X. Ecological carbonated steel slag pervious concrete prepared as a key material of sponge city. J. Clean. Prod. 2020, 256, 120244. [CrossRef]

40. A Salah, B.; Gaber, M.S.; Kandil, T. The Removal of Uranium and Thorium from Their Aqueous Solutions by 8-Hydroxyquinoline Immobilized Bentonite. Minerals 2019, 9, 626. [CrossRef]

41. Nasri, H.; Elhammouti, K.; Azdimousa, A.; Achalhi, M.; Bengamra, S. Calcimetric and sedimentometric characterization of clay deposits in the Neogene Boudinar basin (north eastern Rif, Morocco): Implication on the eustatic and hydrodynamic evolution of the basin and economic interest. J. Mater. Environ. Sci. 2016, 7, 859-870.

42. Sebbahi, S.; Chameikh, M.L.O.; Sahban, F.; Aride, J.; Benarafa, L.; Belkbir, L. Thermal behaviour of Moroccan phosphogypsum. Thermochim. Acta 1997, 302, 69-75. [CrossRef]

43. Kamseu, E.; Lancellotti, I.; Sglavo, V.M.; Modolo, L.; Leonelli, C. Design of inorganic polymer mortar from ferricalsialic and calsialic slags for indoor humidity control. Materials 2016, 9, 410. [CrossRef]

44. Sebbar, N.; Lahmili, A.; Bahi, L.; Ouadif, L. Treatment of clay soils with steel slag, in road engineering. In Proceedings of the Seventh International Congress “Water, Waste and Environment" (EDE7-2019), Sale, Morocc, 20-22 November 2019; Volume 150, p. 02017.

45. Hassoune, H.; Lahhit, M.; Khalid, A.; Lachehab, A. Application of leaching tests on phosphogypsum by infiltration-percolation. Water Sci. Technol. 2017, 76, 1844-1851. [CrossRef] [PubMed]

46. Manzano, H.; Dolado, J.S.; Ayuela, A. Elastic properties of the main species present in Portland cement pastes. Acta Mater. 2009, 57, 1666-1674. [CrossRef]

47. Dihang, M.D. Mécanisme de Coagulation et de Floculation de Suspensions D'argiles Diluées Rencontrées en Traitement des Eaux. Ph.D. Thesis, Université de Toulouse, Université Toulouse III-Paul Sabatier, Toulouse, France, 2007.

48. Gu, Y.; Martin, R.P.; Metalssi, O.O.; Fen-Chong, T.; Dangla, P. Pore size analyses of cement paste exposed to external sulfate attack and delayed ettringite formation. Cem. Concr. Res. 2019, 123, 105766. [CrossRef]

49. Qiao, Z.; Liu, Q.; Zhang, S.; Wu, Y. The mineralogical characteristics between opaline silica in bentonite and $\alpha$-cristobalite. Solid State Sci. 2019, 96, 105948. [CrossRef]

50. Gou, Z.; Chang, J.; Gao, J.; Wang, Z. In vitro bioactivity and dissolution of $\mathrm{Ca}_{2}(\mathrm{SiO} 3)(\mathrm{OH})_{2}$ and $\beta-\mathrm{Ca}_{2} \mathrm{SiO}_{4}$ fibers. J. Eur. Ceram. Soc. 2004, 24, 3491-3497. [CrossRef] 
51. Robinet, L.; Coupry, C.; Eremin, K.; Hall, C. The use of Raman spectrometry to predict the stability of historic glasses. J. Raman Spectrosc. 2006, 37, 789-797. [CrossRef]

52. Matson, D.W.; Sharma, S.K.; Philpotts, J.A. The structure of high-silica alkali-silicate glasses. A Raman spectroscopic investigation. J. Non Crys. Solids 1983, 58, 323-352. [CrossRef]

53. Sharma, S.K.; Mammone, J.F.; Nicol, M.F. Raman investigation of ring configurations in vitreous silica. Nature 1981, 292, 140-141. [CrossRef]

54. McMillan, P. Structural studies of silicate glasses and melts-Applications and limitations of Raman spectroscopy. Am. Mineral. 1984, 69, 622-644.

55. Monnin, Y. Méthodologie Pour Décrire le Gonflement Multi-Echelle de Calcaires Siliceux Soumis à la Réaction Alcali-Silice Dans le Matériau Béton. Ph.D. Thesis, Université d'Artois, Arras, France, 2005.

56. Li, H.; Guan, X.; Zhang, X.; Ge, P.; Hu, X.; Zou, D. Influence of superfine ettringite on the properties of sulphoaluminate cement-based grouting materials. Constr. Build. Mater. 2018, 166, 723-731. [CrossRef]

57. Jiménez, A.; Prieto, M. Thermal stability of ettringite exposed to atmosphere: Implications for the uptake of harmful ions by cement. Environ. Sci. Technol. 2015, 49, 7957-7964. [CrossRef] [PubMed]

Publisher's Note: MDPI stays neutral with regard to jurisdictional claims in published maps and institutional affiliations.

(C) 2020 by the authors. Licensee MDPI, Basel, Switzerland. This article is an open access article distributed under the terms and conditions of the Creative Commons Attribution (CC BY) license (http://creativecommons.org/licenses/by/4.0/). 